\title{
PRZYWRÓCENIE TERMINU W POSTĘPOWANIU ADMINISTRACYJNYM
}

\begin{abstract}
Streszczenie. W postępowaniu administracyjnym obowiązują dwa podstawowe rodzaje terminów. Pierwszy rodzaj terminów to te, które wynikają bezpośrednio z ustawy (terminy ustawowe z kolei dzieli się na zawite i instrukcyjne), drugi rodzaj terminów to terminy dodatkowe wyznaczone przez organ administracyjny prowadzący daną sprawę. Zasadnicza różnica pomiędzy terminami zawitymi i instrukcyjnymi sprowadza się do konsekwencji prawnych, które występują po ich przekroczeniu. W przypadku przekroczenia terminu zawitego przez stronę dochodzi do nieskuteczności podjętych czynności, natomiast przekroczenie terminu zawitego przez organ powoduje z kolei utratę przez niego kompetencji do rozpatrzenia danej sprawy. W przypadku przekroczenia terminu instrukcyjnego nie dochodzi do powstania tak doniosłych konsekwencji prawnych. Terminy instrukcyjne mogą być zarówno wydłużane, jak i skracane. Oznacza to, że strona nie traci definitywnie prawa do występowania z określonymi żądaniami. Warto zaznaczyć jednak że, jeżeli dojdzie do przekroczenia terminu zawitego, to istnieje jeszcze możliwość jego przywrócenia. Przywrócenie terminu następuje zawsze na wniosek strony. W myśl obowiązujących przepisów strona ma siedem dni na złożenie stosownego wniosku. Termin ten liczy się od momentu (od dnia) ustania przyczyny powstania uchybienia.
\end{abstract}

Słowa kluczowe: terminy, zasada obliczania terminów, uchybienie terminu, wniosek o przywrócenie terminu, właściwość organu.

Obowiązujące ustawy, m.in. ustawa z dnia 14 czerwca 1960 r. Kodeks postępowania administracyjnego (KPA) ${ }^{1}$, ustawa z dnia 29 sierpnia 1997 r. Ordynacja podatkowa ${ }^{2}$, ustawa $\mathrm{z}$ dnia 30 sierpnia 2002 r. Prawo o postępowaniu przed sądami administracyjnymi (p.p.s.a.) ${ }^{3}$, nakazują nie tylko organowi administracji załatwienie spraw bez zbędnej zwłoki, lecz także uczestnicy postępowania są

* Wyższa Szkoła Bankowa w Gdańsku, absolwentka Wydziału Prawa i Administracji Uniwersytetu Mikołaja Kopernika w Toruniu oraz Wydziału Nauk Społecznych na kierunku stosunki międzynarodowe o specjalności administracja w Unii Europejskiej Toruńskiej Szkoły Wyższej w Toruniu.

${ }^{1}$ Ustawa z dnia 14 czerwca 1960 r. Kodeks postępowania administracyjnego, t.j. Dz. U. 2010, nr 182, poz. 1128 z późn. zm.

${ }^{2}$ Ustawa z dnia 29 sierpnia 1997 r. Ordynacja podatkowa, t.j. Dz. U. 2009, nr 216, poz. 1676.

${ }^{3}$ Ustawa z dnia 30 sierpnia 2002 r. Prawo o postępowaniu przed sądami administracyjnymi, t.j. Dz. U. 2010. 
dyscyplinowani przez przepisy i powinni pilnować, by zmieścić się w terminach ${ }^{4}$ wyznaczonych przez prawo. Co zrobić, gdy zabiegani i zaabsorbowani codziennymi problemami przeoczymy termin wyznaczony do załatwienia sprawy, na której nam bardzo zależy? Czy mamy realne możliwości na odzyskanie utraconych terminów i doprowadzenie naszej sprawy do końca?

Strona postępowania, która nie wykonała określonych czynności w wyznaczonym terminie przed właściwym organem administracji publicznej, może wystąpić o jego przywrócenie. Niedotrzymanie terminu do wniesienia środków odwoławczych powoduje dla strony poważne konsekwencje, tzn. traci ona uprawnienie do złożenia odwołania, przez co decyzja staje się ostateczna. Zgodnie z powyższym może także wnieść skargę do sądu administracyjnego, gdyż niewyczerpane zostały środki odwoławcze. Wówczas rozstrzygnięcie staje się prawomocne. Nie oznacza to jednak, że strona pozbawiona jest możliwości odwrócenia niekorzystnych dla siebie skutków. Po spełnieniu określonych w KPA warunków może on wystąpić do organu administracji publicznej o przywrócenie terminu na wniesienie środków odwoławczych. Zgodnie z art. 58 KPA można stwierdzić, iż przywrócenie terminu następuje po wystosowaniu przez dany podmiot jakiejś nieformalnej prośby do właściwego organu, który to organ w sposób równie nieformalny może wedle uznania taką prośbę rozpatrzyć bądź pozostawić bez rozstrzygnięcia. Powyższe stwierdzenie jest jednak niewłaściwe w zastosowaniu, jest skutkiem przeniesienia pojęcia ,prośby” z uchylonego już art. 41 ust. 1 Rozporządzenia Prezydenta RP z dnia 22 marca 1928 r. o postępowaniu administracyjnym ${ }^{5}$ na łamy obecnie obowiązującego kodeksu. Zgodnie z ogólnymi regułami rządzącymi postępowaniem administracyjnym, złożenie prośby o przywrócenie terminu określone w art. 58 KPA oznacza złożenie wniosku, do którego rozpatrzenia organ administracji jest zobowiązany (nie chodzi więc tylko o uzupełnienie braków). Pamiętać tu należy, iż wniosek o przywrócenie terminu, noszący nazwę ,prośby”, stanowi podanie w rozumieniu art. $63 \mathrm{KPA}$, w związku z czym musi spełniać wymogi przewidziane przez ten przepis zarówno dla formy i treści podania, jak i dla sposobów wnoszenia do organu administracji publicznej. Użycie w treści pisma określeń „prośba” czy też „prośba o przywrócenie terminu” nie ma znaczenia dla zakwalifikowania podania według jego treści ${ }^{6}$. W praktyce złożenie wniosku o przywrócenie oraz dokonanie

${ }^{4} \mathrm{~W}$ nauce prawa ,terminem nazywa się zastrzeżenie dodatkowe czynności prawnej, przez które jej skutek zostaje ograniczony w czasie”, A. Wolter, Prawo cywilne. Zarys części ogólnej, PWN, Warszawa 1967, s. 268. „Zastrzeżenie dodatkowe czynności prawnej jest wprowadzone zarówno w przepisach prawa materialnego, jak i prawa procesowego. Od jego spełnienia uzależniona jest w wielu przepisach prawa możliwość podjęcia skutecznej ochrony interesu prawnego przez jednostkę”. B. Adamiak, J. Borkowski, Postępowanie administracyjne i sq̨dowoadministracyjne, Wydawnictwo Prawnicze Lexis Nexis, Warszawa 2007, s. 406.

${ }^{5}$ Rozporządzenia Prezydenta RP z dnia 22 marca 1928 r., Dz. U. 1928, nr 38, poz. 341 z późn. zm.

${ }^{6}$ Wyrok Naczelnego Sądu Administracyjnego z dnia 22 stycznia 1988 r., sygn. akt. SA/Wr 815/87 ONSA 1988, nr 1, poz. 31. 
czynności procesowej, dla której ustalony był termin, mogą nastąpić w tym samym piśmie. W kwestii tej wypowiedział się w wyroku z dnia 11 września 2001 r. Naczelny Sąd Administracyjny stwierdzając, iż „To, że skarżąca nie złożyła odrębnego pisma, nie oznacza, że wniosek o przywrócenie terminu do wniesienia odwołania nie jest równocześnie odwołaniem"’. Zdaniem Naczelnego Sądu Administracyjnego ,W skrajnym przypadku, wniesienie odwołania po terminie i zawarcie $\mathrm{w}$ nim argumentacji (usprawiedliwiającej brak winy) i prośby o rozpoznanie sprawy mimo tego, można również odebrać jako prośbę o przywrócenie terminu"». Art. $58 \S 1$ KPA nie ogranicza uprawnień zainteresowanego do przywrócenia terminów określonego rodzaju, a zatem należy przyjąć, iż może on żądać przywrócenia zarówno ustawowych, jak i urzędowych terminów dokonania czynności procesowych, czyli m.in. dotyczących wniesienia środków odwoławczych bądź uzupełnienia braków wniesionego do urzędu podania o wszczęcie postępowania administracyjnego. Nie jest jednak dopuszczalne przywrócenie tzw. terminów materialnych ${ }^{9}, \mathrm{np}$. terminu uchylenia decyzji w trybie wznowienia postępowania (art. $146 \S 1 \mathrm{KPA}$, terminu stwierdzenia nieważności decyzji (art. $156 \S 2 \mathrm{KPA})^{10}$. Naruszenie tej zasady stanowi podstawę do stwierdzenia nieważności wydawanego w tej sprawie postanowienia. Uchybienie terminu materialnoprawnego powoduje skutek wygaśnięcia praw lub obowiązków o charakterze materialnoprawnym ${ }^{11}$ lub wywołuje skutek prawny materialnej trwałości ukształtowanych praw przez wyłączenie dopuszczalności uchylenia decyzji lub wyłączenie dopuszczalności stwierdzenia nieważności decyzji. Terminem procesowym jest okres do dokonania czynności procesowej przez podmioty postępowania lub czynników postępowania. Różnica pomiędzy terminami materialnym a terminem procesowym sprowadza się do różnych skutków prawnych ich uchybienia. Uchybienie terminu procesowego wywołuje skutek prawny w płaszczyźnie procesowej przez uzależnienie skuteczności procesowej od zachowania terminu. Należy zwrócić uwagę, iż bezskuteczność czynności procesowej może prowadzić do zamknięcia drogi sądowej, co w następstwie prowadzi do uniemożliwienia podjęcia obrony interesu prawnego przez jednostkę, a zatem do weryfikacji materialnej ukształtowanych praw w wyniku działania administracji publicznej, np. do zmiany prawa ukształtowanego decyzją administracyjną. Strona, podmiot na prawach strony, uczestnik postępowania może jednak bronić się przed

7 Wyrok z dnia 11 września 2001 r., sygn. akt I SA 637/00, niepubl.

${ }^{8}$ Wyrok Naczelnego Sądu Administracyjnego z dnia 14 maja 1998 r., sygn. akt. IV SA 1153/96, niepubl.

9 Terminem materialnym jest okres, w którym może nastąpić ukształtowanie praw i obowiązków jednostki w formie autorytatywnej konkretyzacji normy prawa materialnego lub bezpośrednio z mocy prawa. B. Adamiak, J. Borkowski, op. cit., s. 406-407.

10 B. Adamiak, Komentarz, [w:] B. Adamiak, J. Borkowski, Kodeks postępowania administracyjnego. Komentarz, Lexis Nexis, Warszawa 1996, s. 291.

11 J. Pokrzywnicki, Postepowanie administracyjne. Komentarz - podręcznik, Nakł. Gospodarczego Zrzeszenia Samorządu Terytorialnego, Warszawa 1948, s. 112. 
negatywnymi skutkami uchybienia terminu czynności procesowej, wnosząc prośbę o przywrócenie terminu.

Podział na terminy materialne i terminy procesowe jest istotny w postępowaniu sądowoadministracyjnym. Podstawową rolę odgrywają terminy procesowe, ale $\mathrm{w}$ zakresie orzekania sąd administracyjny jest obowiązany uwzględnić terminy materialne, np. w zakresie dopuszczalności uchylenia decyzji (art. $146 \S 1$ KPA, art. $245 \S 1$ pkt 3 lit. a. o.p.), stwierdzenia nieważności decyzji (art. $156 \S 2$ KPA, art. 247 § 3 o.p.). W związku z powyższym, strona wystąpiła do prezydenta miasta $\mathrm{z}$ wnioskiem o przywrócenie terminu do wpłaty drugiej raty opłaty za korzystanie z zezwolenia na sprzedaż napojów alkoholowych. W uzasadnieniu wniosku wyjaśniła, iż opóźnienie w opłacie wynikło z przyczyn od niego niezależnych. W momencie upływu terminu był on chory. W odpowiedzi na jego wniosek prezydent miasta stwierdził, że termin na wniesienie opłaty za korzystanie z zezwolenia na sprzedaż alkoholu jest terminem materialnym, który nie może być przywrócony (wyrok z dnia 22 stycznia 2008 r. Wojewódzkiego Sądu Administracyjnego w Warszawie ${ }^{12}$ ). W myśl art. 58 § $1 \mathrm{KPA}$ przywrócenie terminu może nastąpić wyłącznie na wniosek osoby zainteresowanej. Pojęcie to zostało zastosowane przez ustawodawcę celowo, aby rozszerzyć krąg osób legitymowanych do podjęcia tego rodzaju czynności prawnej. Kierując się stanowiskiem doktryny, za osoby zainteresowane poza stronami należy uznać osoby mające w postępowaniu interes faktyczny oraz osoby uczestniczące jedynie w niektórych czynnościach procesu, np. biegli, świadkowie. W kwestii tej w wyroku Naczelnego Sądu Administracyjnego z dnia 24 listopada 2010 r. stwierdził, iż:

1. Strona postępowania administracyjnego, niebędąca jedyną stroną postępowania, która została w tym postępowaniu pominięta przez niedoręczenie jej decyzji organu pierwszej instancji, może wnieść odwołanie w terminie, który biegnie dla stron postępowania, którym decyzję doręczono, zaś po tym terminie nie służy jej prawo wniesienia odwołania, lecz podanie o wznowienie postępowania na podstawie art. $145 \S 1$ pkt 4 k.p.a. 2. Możliwość skorzystania z wniosku o przywrócenie terminu do wniesienia odwołania służy jedynie stronie, której organ doręczył decyzję.

Organ administracji nie ma kompetencji do przywrócenia terminu z urzę$\mathrm{du}$, nawet $\mathrm{w}$ sytuacji gdy jest przekonany o braku winy podmiotu, który dokonał czynności procesowej po upływie terminu ${ }^{13}$. W kwestii tej wypowiedział się w wyroku z dnia 18 czerwca 1998 r. Naczelny Sąd Administracyjny w Poznaniu który stwierdził, iż organy administracyjne nie mogą bez wyraźnego wniosku zainteresowanego przywrócić terminu do dokonania określonej czynności. Organ postępowania nie ma obowiązku informowania strony o prawie do wniesienia

12 Wyrok Wojewódzkiego Sądu Administracyjnego w Warszawie z dnia 22 stycznia 2008 r. sygn. akt. VI SA/Wa 1845/07.

13 Wyrok Naczelnego Sądu Administracyjnego w Warszawie z dnia 17 lutego 2012 r., sygn. akt. II OSK 2287/2010. 
przez nią wniosku o przywrócenie terminu do dokonania określonej czynności ${ }^{14}$. Również Naczelny Sąd Administracyjny w Poznaniu w wyroku z dnia 29 października 1996 r. stwierdził, iż trudno wymagać, aby organ podatkowy z własnej inicjatywy pouczał stronę o przysługującym jej prawie wniesienia prośby o przywrócenie terminu, tym bardziej, że na tym etapie postępowania nie była temu organowi znana data ustania przyczyny uchybienia terminu. Wyjątek mogą stanowić szczególnie sytuacje dotyczące przedmiotu postępowania lub cech strony, np. nie ma ona podstawowej wiedzy o przepisach prawa ${ }^{15}$. W myśl art. $58 \S 1$ i 2 KPA oraz art. $162 \S 1$ i 2 ustawy ordynacji podatkowej wniosek o przywrócenie terminu powinien zawierać 4 elementy, które muszą zostać spełnione łącznie. A contrario należy twierdzić, iż w przypadku niedochowania przynajmniej jednej z nich organ administracyjny jest zobowiązany wydać postanowienie odmowne w przedmiocie przywrócenia terminu. Do omawianych przesłanek zalicza się:

1) uprawdopodobnienie przez osobę zainteresowaną braku swojej winy (należy przyjąć tu obiektywny miernik staranności) ${ }^{16}$;

2) wniesienie przez osobę zainteresowaną wniosku o przywrócenie terminu (organ administracji nie może w drodze interpretacji treści oświadczenia domniemywać, że strona wniosła o przywrócenie terminu);

3) dochowanie terminu do wniesienia wniosku;

4) dopełnienie wraz z wnioskiem o przywrócenie terminu tej czynności, dla której ten termin był ustanowiony, jednocześnie ze złożeniem wniosku o przywrócenie terminu. Organ administracji publicznej prowadzący postępowanie nie jest obowiązany do pouczenia strony o prawie do żądania przywrócenia terminu ${ }^{17}$.

${ }^{14}$ Wyrok Naczelnego Sądu Administracyjnego w Poznaniu w wyroku z dnia 18 czerwca 1998 r., sygn. akt. I SA/Po 1911/97.

${ }^{15}$ Naczelny Sąd Administracyjny w Poznaniu w wyroku z dnia 29 października 1996 r., sygn. akt. I SA/Po233/96.

${ }^{16}$ Zgodnie z art. 162 § 1 i 2 ordynacji podatkowej strona musi uprawdopodobnić, że uchybienie terminowi nastąpiło bez jej winy. Pomimo że ordynacja podatkowa posługuje się pojęciem „uprawdopodobnienie”, a nie „udowodnienie” spełnienie tego warunku w praktyce nie jest łatwe. Od strony postępowania podatkowego wymaga się szczególnej staranności i dbałości o realizację własnych interesów i to nie tylko w odniesieniu do działań realizowanych w związku z postępowaniem, ale i poza nim. $Z$ sentencji jednego z niepublikowanych orzeczeń Naczelnego Sądu Administracyjnego z dnia 12 lutego 1997 r. (sygn. akt I Sa/Gd 1453/96) wynika, iż „rzeczą podmiotu prowadzącego działalność gospodarczą, korzystającego z obsługi prawnej, jest przeszkolenie podległych pracowników, tak co do prawidłowego odbioru korespondencji, jak i jej obiegu celem zachowania terminów złożenia odwołania. Wszelkie błędy popełnione przez podległych pracowników, tak co do prawidłowego odbioru korespondencji, jak i jej obiegu celem zachowania terminów złożenia odwołania. Wszelkie błędy popełnione przez podległych pracowników obciążają [...] pracodawcę". Stąd wynika, iż jeżeli strona wykaże, że powodem niedopełnienia terminu (np. wniesienia odwołania) było przeoczenie pracownika, który zapomniał przekazać doręczoną decyzję podatkową, organ postanawiający o przywróceniu terminu będzie miał prawo nie uwzględnić tego argumentu.

${ }_{17}$ Wyrok Naczelnego Sądu Administracyjnego z dnia 11 lutego 2014 r., sygn. akt. IIOSK 2188/12. LEX nr 1450897. 
Dopuszczalność przywrócenia terminu w postępowaniu sądowoadministracyjnym jest obwarowana przesłankami materialnymi i formalnymi. Przesłanki materialne, które muszą wystąpić łącznie, to:

1) uchybienie terminu przez stronę bez własnej winy: „Kryterium braku winy jako przesłanka zasadności wniosku o przywrócenie terminu wiążą się z obowiązkiem strony do szczególnej staranności przy dokonywaniu czynności procesowej. Przywrócenie nie jest więc dopuszczalne, gdy strona dopuściła się choćby lekkiego niedbalstwa $[\ldots]]^{\prime 18}$. Przy tej przesłance materialnej należy też zwrócić uwagę na to, że po upływie roku od uchybionego terminu jego przywrócenie jest dopuszczalne tylko w przypadkach wyjątkowych;

2) przywrócenie terminu nie jest dopuszczalne, jeżeli uchybienie terminu nie powoduje dla strony ujemnych skutków w zakresie postępowania sądowego.

Przesłanki formalne przywrócenia terminu:

1) złożenie przez stronę wniosku w formie pisma procesowego o przywrócenie terminu. We wniosku o przywrócenie terminu strona musi uprawdopodobnić, iż brak winy jest brakiem formalnym wniosku;

2) równocześnie z wnioskiem należy dopełnić czynności procesowej, dla której został ustanowiony termin;

3) pismo z wnioskiem o przywrócenie terminu musi zostać złożone w ciągu 7 dni od czasu ustania przyczyny uchybienia terminu.

Termin do złożenia wniosku jest terminem ustawowym i na ogólnych zasadach może zostać przywrócony ${ }^{19}$. Przy czym zawarta w nim prośba o przywrócenie terminu musi być wyraźna i jednoznaczna (wyrok Naczelnego Sądu Administracyjnego z dnia 16 lipca $2013 \mathrm{r}^{20}$ ). Zgodnie z art. 58 § $2 \mathrm{Kpa}$ oraz 87 $\S 1$ i n. p.p.s.a. wniosek ten musi zostać złożony do organu administracji publicznej w ciągu 7 dni od dnia ustania przyczyny uchybienia terminowi. Pamiętajmy, iż 7-dniowy termin do wniesienia prośby o przywrócenie terminu jest terminem prekluzyjnym i nie podlega przywróceniu ${ }^{21}$. Ponadto zainteresowany powinien jednocześnie z wniesieniem żądania o przywrócenie terminu dopełnić czynności, dla której określony był termin. Gdy zatem strona wnosi o przywrócenie terminu wniesienia odwołania, powinna jednocześnie wnieść odwołanie. W razie gdy do organu właściwego wpłynie jedynie wniosek o przywrócenie terminu, organ ten może odmówić przywrócenia tego terminu, jeżeli do dnia doręczenia żądania organowi nie dopełniono czynności, dla której ustanowiono termin. Pogląd, że dopełnienie czynności jest koniecznym warunkiem przywrócenia terminu, jeżeli

18 J. Krajewski, [w:] J. Jodłowski, K. Piasecki (red.), Kodeks postępowania cywilnego z komentarzem, Wydawnictwo Prawnicze, Warszawa 1989, s. 274.

19 B. Adamiak, J. Borkowski, op. cit., s. 410.

${ }^{20}$ Wyrok Naczelnego Sądu Administracyjnego w Warszawie z dnia 16 lipca 2013 r., sygn. akt. II GSK 503/2012.

${ }^{21}$ Wyrok Naczelnego Sądu Administracyjnego z dnia 8 lutego 2001 r., sygn. akt III SA 551/00, niepubl. 
do dopełnienia czynności nie jest potrzebna czynność organu ${ }^{22}$, nie jest trafny, ponieważ przywracalne są jedynie terminy dokonania czynności procesowych przez strony i uczestników postępowania ${ }^{23}$. Od zasady zawartej w art. $87 \S 1$ p.p.s.a. jest wprowadzony wyjątek co do trybu wniesienia wniosku o przywrócenie terminu do złożenia skargi. „Wniosek o przywrócenie terminu do wniesienia skargi wnosi się za pośrednictwem organu, którego działanie lub bezczynności organu, którego działanie lub bezczynność są przedmiotem skargi” (art. 87 § 3 p.p.s.a.). Zasada ta obowiązuje także na gruncie ustawy ordynacji podatkowej (art. 162 $\S 1$ o.p.). Przywrócenie terminu złożenia tego wniosku ma szczególny charakter niedopuszczalny (art. $162 \S 3$ o.p.). Ten tryb pośredni składania wniosku jest obowiązujący zarówno, gdy skarżący składa wniosek o przywrócenie terminu do złożenia skargi, jak i gdy po złożeniu skargi sąd odrzucił skargę z powodu upływu terminu do jej wniesienia. Ten tryb pośredni ma zapewnić organowi, którego działania lub bezczynności skarga dotyczy, możliwość ustosunkowania się co do przedstawionych okoliczności uprawdopodobniających brak winy strony skarżącej zachowania terminu ${ }^{24}$, a w pierwszej sytuacji ponadto przekazania akt sprawy do sądu. Organ, którego działania lub czynności skarga dotyczy, nie jest właściwy do wyprowadzenia skutków prawnych uchybienia przez stronę skarżącą terminu. Obowiązany jest w takim przypadku postąpić zgodnie z regułami ogólnymi, a zatem przekazać do sądu skargę, akta sprawy i odpowiedź na skargę. W treści wniosku o przywrócenie terminu przedsiębiorca musi uwiarygodnić przez przedstawienie stosownej argumentacji, że dochował on należnej staranności, jednak dopełnienie czynności w terminie stało się niemożliwe z powodu trudnej do przezwyciężenia przeszkody od niego niezależnej i istniejącej przez cały czas aż do wniesienia wniosku. Pamiętajmy, iż brak winy jako przesłanka zasadności wniosku o przywrócenie terminu wiąże się z obowiązkiem strony do zachowania staranności przy dokonywaniu czynności procesowych i można mówić o niej tylko wówczas, gdy dopełnienie czynności w terminie stało się niemożliwe z powodu trudnej do przezwyciężenia przeszkody niezależnej od strony. Za taką przeszkodę nie może być uznany fakt, iż skarżący nieprawidłowo ustalił datę końcową terminu do uiszczenia wpisu ${ }^{25}$. Warunkiem dopuszczalności przywrócenia stronie

${ }^{22}$ E. Iserzon, J. Starościak, Kodeks postępowania administracyjnego. Komentarz, teksty, wzory i formularze, Wydawnictwo Prawnicze, Warszawa 1970, s. 138.

${ }^{23}$ Wyrok NSA z dnia 14 maja 2007 r., sygn. akt. II OSK 762/06, LEX nr 347861.

${ }^{24}$ Wyroku Naczelnego Sądu Administracyjnego z dnia 14 maja 1991 r, sygn. akt. II SA 340/91, ONSA 1991, nr 3-4 poz. 60, przyjęto, iż „Z art. 58 kpa wynika, że uprawdopodobnienie braku winy powinno odnosić się wyłącznie do kwestii przyczyn niedotrzymania terminu, a nie być skierowane przeciwko podstawie prawnej lub okolicznościom faktycznym dotyczącym samej decyzji”. Z kolei w wyroku Naczelnego Sądu Administracyjnego z dnia 11 września 2008 r., sygn. akt. II OSK 1015/07, trafnie stwierdzono, że uprawdopodobnienie braku winy w uchybieniu terminowi musi dotyczyć tego i tylko okresu, w którym miała być dokonana czynność procesowa.

${ }_{25}$ Wyrok Naczelnego Sądu Administracyjnego z dnia 8 lipca 1998 r., sygn. akt I SA/Lu 727/97, niepubl. 
terminu do dokonania czynności procesowej, stosownie do art. $58 \S 1 \mathrm{KPA}$, jest uprawdopodobnienie przez stronę, że mimo całej staranności nie mogła dokonać czynności w terminie, to znaczy, iż zachodziły przeszkody od niej niezależne oraz istniejące przez cały czas biegu terminu przewidzianego dla dokonania czynności procesowej. Okoliczność sprowadzająca się do kwestionowania treści uzasadnienia i wskazywania jego braków w żadnym wypadku nie może zostać zakwalifikowana jako obiektywnie istniejąca przesłanka uniemożliwiająca wniesienie przez skarżącego odwołania w terminie ${ }^{26}$. Nie trzeba więc przeprowadzać w tym zakresie dowodu, który brak winy czyniłby faktem absolutnie pewnym. W związku z tym należy wskazać takie okoliczności, które umożliwiają organowi administracji publicznej powzięcie przekonania o prawdopodobieństwie braku winy $\mathrm{w}$ uchybieniu terminu po stronie zainteresowanego ${ }^{27}$. W wyroku Naczelnego Sądu Administracyjnego z dnia 14 maja 1991 r. przyjęto: „Z art. 58 k.p.a. wynika, iż uprawomocnienie braku winy powinno odnosić się wyłącznie do kwestii przyczyn niedotrzymania terminu, a nie być skierowane przeciwko podstawie prawnej lub okolicznościom faktycznym dotyczącym samej decyzji” ${ }^{28}$. Do okoliczności faktycznych uzasadniających brak winy w uchybieniu terminu przez zainteresowanego zalicza się np.: przerwę w komunikacji, nagłą chorobę, która nie pozwoliła na wyręczenie się inną osobą ${ }^{29}$, powódź, pożar, lecz już nie oczekiwanie na poradę radcy prawnego ${ }^{30}$, a także nieprawidłowe doręczenie pis-

${ }^{26}$ Wyrok Naczelnego Sądu Administracyjnego z dnia 13 października 1999 r., sygn. akt. IV SA 1656/97, niepubl.

${ }^{27}$ R. Orzechowski, [w:] J. Borkowski, J. Jendrośka, R. Orzechowski, A. Zieliński, Kodeks postępowania administracyjnego. Komentarz, Warszawa 1985, s. 145; odnośnie do instytucji uprawdopodobnienia zob. $\mathrm{Nb} 16$ komentarza do art. 24.

${ }^{28}$ Wyrok Naczelnego Sądu Administracyjnego z dnia 14 maja 1991 r., sygn. akt. IISA 340/91, ONSA 1991, nr 3, poz. 60.

${ }^{29}$ Zwolnienie lekarskie nie jest potwierdzeniem braku winy zainteresowanego w uchybieniu terminu. Nie wyklucza ona możliwości dokonania czynności procesowej przez stronę (np. sporządzenie odwołania i nadania go przez pocztę osobiście lub przez domownika (wyrok z dnia 10 marca 1998 r., sygn. akt I SA/Po 865/97, Lex nr 32159). Choroba wymagająca leżenia nie uzasadnia sama przez się braku zawinienia i przywrócenia terminu do dokonania czynności procesowej, o ile osoba uprawniona do dokonania tej czynności mogła skorzystać z pomocy osób trzecich (wyrok Naczelnego Sądu Administracyjnego z dnia 31 stycznia 2012 r., sygn. akt. II OSK 2175/10, LEX nr 1138097).

${ }^{30}$ Wyrok Wojewódzkiego Sądu Administracyjnego w Łodzi z dnia 5 października 2010 r., sygn. akt. I SA/Sz526/11 oraz Wyrok Naczelnego Sądu Administracyjnego z dnia 26 listopada 1997 r., sygn. akt ISA/Lu 1219/96, lex nr 31857 stwierdził, iż oczekiwanie na poradę radcy prawnego nie jest przesłanką uprawdopodabniającą brak winy strony w uchybieniu terminu do dokonania czynności procesowej oraz samo zwolnienie od pracy nie może być wyłącznie potwierdzeniem braku winy zainteresowanego w uchybieniu terminowi; tak samo nie może wyłączać zawinienia fakt czasowego przebywania zainteresowanego poza miejscem stałego zamieszkania, jeżeli doszło w tym czasie do skutecznego doręczenia zaskarżonego postanowienia (niepublikowany wyrok NSA w Katowicach z dnia 20 kwietnia 1999 r., I SA/Ka 1609/97, LEX nr 37821); osoba uprawniona do dokonania tej czynności mogła skorzystać z pomocy osób trzecich (wyrok NSA z dnia 
$\mathrm{ma}^{31}$, jak i naruszenie przez organ administracji publicznej ustanowionego w art. 9 KPA obowiązku informowania stron ${ }^{32}$. Podobnie w niepublikowanym wyroku Naczelnego Sądu Administracyjnego z dnia 4 listopada 1998 r., III SA 1243/97, LEX nr 36902, w którym stwierdzono, że:

Zwolnienie lekarskie od pracy nie jest potwierdzeniem braku winy zainteresowanego w uchybieniu terminu. Nie wyklucza bowiem ono możliwości dokonania czynności procesowej przez strony (np. sporządzania odwołania) i nadania pisma przez pocztę osobiście lub przez domownika ${ }^{33}$.

Trudności w prowadzeniu działalności gospodarczej i inwestycyjnej, pomocy żonie w prowadzeniu firmy, a także kłopotów w kontaktowaniu się z doradcą podatkowym nie można zaliczyć do przyczyn uzasadniających przyjęcie, że uchybienie terminowi nastąpiło bez winy zainteresowanego, nawet obciążonego tymi problemami, bowiem są to przyczyny subiektywne, którym skarżący przy zachowaniu należytej staranności mógł zaradzićc ${ }^{4}$. Nieznajomość przepisów postępowania nie może być uznana za niezawinioną przyczynę uchybienia dokonania czynności procesowej w terminie ${ }^{35}$. Istnienie choćby winy nieumyślnej, niedbalstwa po stronie zobowiązanego do dokonania czynności stanowi negatywną przesłankę do przywrócenia terminu na zasadzie art. $58 \S 1$ $\mathrm{KPA}^{36}$. Nie można zaakceptować braku reprezentacji spółki podczas nieobecności jednego członka jej zarządu jako przyczyny usprawiedliwiającej uchybienie

31 stycznia 2012 r., II OSK 2175/10, LEX nr 1138097) oraz oczekiwanie na poradę radcy prawnego nie jest przesłanką uprawdopodobniającą brak winy strony w uchybieniu terminowi dokonania czynności procesowej (niepublikowany wyrok NSA w Lublinie z dnia 26 listopada 1997 r., I SA/ Lu 1219/96, LEX nr 31857).

${ }^{31}$ Wyrok Naczelnego Sądu Administracyjnego z dnia 14 grudnia 2000 r., sygn. akt. IV SA 2121/98 oraz zaginięcie decyzji, którą doręczono, skutkujące uchybieniem terminowi do wniesienia środka odwoławczego, w żadnym razie poza oczywistymi przypadkami działania siły wyższej nie stanowi o braku winy - wyrok Naczelnego Sądu Administracyjnego z dnia 16 października 1999 r., sygn. akt. IV SA 674/00, niepubl.

32 Wyrok Naczelnego Sądu Administracyjnego z dnia 15 października 1992 r., sygn. akt. SA/ Ka 766/92, OSP 1994, nr 5, poz. 100 z glosą aprobującą J. Borkowskiego.

33 Wyrok Naczelnego Sądu Administracyjnego z dnia 4 listopada 1998 r., sygn. akt. III SA 1243/97, LEX nr 36902, niepubl.

${ }^{34}$ Wyrok NSA w Poznaniu z dnia 18 listopada 1997 r., sygn. akt. I SA/Po 1868/96, niepubl.

35 Postanowienie Sądu Najwyższego z dnia 25 lutego 1998 r., sygn. akt. II UKN 519/97, opublikowane w OSNP 1999/1/36/ oraz wyrok Naczelny Sąd Administracyjny w Warszawie z dnia 29 sierpnia 1997 r., III SA 101/96 nieopublikowany oraz „przeoczenie” wynikające ze słabej znajomości procedury (wyrok Naczelnego Sądu Administracyjnego w Warszawie z dnia 8 maja 2001 r., V SA 1150/00, LEX nr 109294); nieznajomość prawa polskiego i postępowania przed organami państwowymi (Wyrok Naczelnego Sądu Administracyjnego w Warszawie 10 grudnia 1999 r., sygn. akt. V SA 946/99, LEX nr 49950).

${ }^{36}$ Wyrok Naczelnego Sądu Administracyjnego w Szczecinie z dnia 22 maja 1997 r., sygn. akt. SA/Sz 630/96, niepubl. 
terminowi ${ }^{37}$ oraz nieprawidłowości organizacyjne jednostki lub zaniedbania jej pracowników ${ }^{38}$. Brak staranności strony $\mathrm{w}$ zapoznaniu się z treścią pouczeń zawartych $\mathrm{w}$ doręczonych decyzjach ${ }^{39}$ oraz niewywiązanie się z przyjętego obowiązku oddania decyzji jej adresatowi przez osobę, której doręczono decyzję zastępczo, nie zwalnia adresata $\mathrm{z}$ winy, w razie gdy uchybił on terminom procesowym na skutek takiego zaniedbania ${ }^{40}$. Okoliczność, że wnioskodawca nie czytuje prasy i nie ogląda telewizji ${ }^{41}$, a także nieskorzystanie przez stronę, która przez kilka miesięcy miała problemy z wysłaniem wniosków o refundację drogą elektroniczną, z podręcznika wypełniania wniosków dostępnego na stronie internetowej funduszu oraz nieupewnienie się, czy którykolwiek z wniosków został skutecznie wysłany ${ }^{42}$. Trudności strony w obsłudze systemu elektronicznego SODiR, a także „oporność” systemu nie stanowią podstaw uzasadniających zastosowanie w sprawie art. $58 \S 2 \mathrm{KPA}^{43}$.

Ustawodawca celowo dopuszcza środek dowodowy mniej pewny, aby tym samym ułatwić zainteresowanemu przedstawienie, iż uchybienie terminu nastąpiło bez jej winy (wyrok Wojewódzkiego Sądu Administracyjnego w Warszawie z dnia 6 sierpnia $2009 \mathrm{r}^{44}$ ). W literaturze przyjmuje się, iż o braku winny w niedopełnieniu obowiązku można mówić tylko w przypadku stwierdzenia, że dopełnienie obowiązku stało się niemożliwe z powodu przeszkody, której osoba zainteresowana nie mogła usunąc nawet przy użyciu największego w danych warunkach wysiłku ${ }^{45}$. Naczelny Sąd Administracyjny podkreśla, iż „strona obowiązana jest do zachowania szczególnej staranności przy dokonywaniu czynności procesowej, zatem przywrócenie terminu nie jest dopuszczalne, gdy strona dopuściła się choćby lekkiego niedbalstwa"46. Na przykład przedsiębiorca w dniu 7 kwietnia 2014 r.

37 Wyrok Naczelnego Sądu Administracyjnego w Krakowie z dnia 8 marca 1995 r., sygn. akt. $\mathrm{SA} / \mathrm{Kr} 2742 / 94$, niepubl.

${ }^{38}$ Wyrok Naczelny Sądu Administracyjnego w Warszawie z dnia 20 września 2001 r., sygn. akt. IV SA 1340/99, LEX nr 54141.

${ }^{39}$ Wyrok Naczelnego Sądu Administracyjnego w Gdańsku z dnia 21 maja 1999 r., sygn. akt. I SA/Gd 2243/98, LEX nr 38700.

${ }^{40}$ Wyrok Naczelnego Sądu Administracyjnego z dnia 20 lutego 2009 r., sygn. akt. I OSK 480/08.

41 Wyrok Naczelnego Sądu Administracyjnego z dnia 23 lipca 2008 r., sygn. akt. I OSK 1350/07, LEX nr 493244.

${ }^{42}$ Wyrok Wojewódzkiego Sądu Administracyjnego w Warszawie z dnia 15 kwietnia 2010 r., sygn. akt. V SA/Wa 152/10.

${ }^{43}$ Wyrok Wojewódzkiego Sądu Administracyjnego w Warszawie z dnia 17 marca 2010 r., sygn. akt. V SA/Wa 1876/09.

${ }^{44}$ Wyrok Wojewódzkiego Sądu Administracyjnego w Warszawie z dnia 6 sierpnia 2009 r., sygn. akt. IISA/Wa 404/09.

${ }^{45}$ E. Isetrzon, [w:] E. Isetrzon, J. Starościak, Prawo administracyjne podstawowe instytucje, Wydawnictwo Prawnicze, Warszawa 1968, s. 136 oraz wyrok Naczelnego Sądu Administracyjnego z dnia 8 grudnia 1999 r., sygn. akt. ISA/Lu 1246/98, niepubl.

46 Wyrok Naczelnego Sądu Administracyjnego z dnia 4 października 2000 r., sygn. akt. I SA/ Gd 560/00. 
wniósł odwołanie za pomocą faksu. Urząd w skierowanym do niego wezwaniu z dnia 24 kwietnia 2014 r. zobowiązał go do uzupełnienia w terminie siedmiu dni braków formalnych polegających na braku podpisu. $Z$ treści wezwania nie wynikało, że podpis musi być własnoręczny. Przedsiębiorca podpisał odwołanie, ale ponownie wysłał je faksem. Urząd pozostawił je bez rozpoznania. We wniosku o przywrócenie terminu przedsiębiorca wskazał, iż wezwanie o brakach formalnych zrozumiał w ten sposób, że odwołanie nie jest w ogóle podpisane. Wniosek został rozpatrzony negatywnie. Zdaniem urzędu przedsiębiorca nie uprawdopodobnił braku winy w uchybieniu terminu do uzupełnienia podpisu pod własnym odwołaniem. Sąd uchylił to rozstrzygnięcie. Stwierdził, iż treść wezwania skierowana do skarżącego była nieprecyzyjna i mogła wprowadzić stronę w błąd co do sposobu uzupełnienia braków formalnych odwołania. A zatem nieuzupełnienie w terminie braków formalnych odwołania nastąpiło z przyczyn niezależnych od strony, co przedsiębiorca we wniosku uprawdopodobnił ${ }^{47}$. W związku z tym należy pamiętać, iż oceniając brak winy, organ administracji publicznej powinien przyjąć „obiektywny miernik staranności, jakiej można wymagać od strony dbającej należycie o swoje interesy" 48 . Przy zastosowaniu tego miernika przywrócenie terminu nie byłoby dopuszczalne, gdy strona dopuściła się choćby lekkiego niedbalstwa ${ }^{49}$. $\mathrm{W}$ doktrynie postępowania administracyjnego przyjmuje się, iż brak winy strony zachodzi ,tylko wtedy, gdy strona nie mogła usunąć przeszkody, nawet przy użyciu największego w danych warunkach wysiłku”50. W konsekwencji „,pojęcie braku winy w niedopełnieniu czynności procesowej w terminie obejmuje istotnie przeszkody nie do przezwyciężenia, czyli siły wyższej”51. „Jeżeli nawet przeszkoda nie do przezwyciężenia obiektywnie nie istniała, ale strona miała podstawę do sądzenia, iż taka przeszkoda istnieje, należy uznać, że niedopełnienie czynności procesowej było niezawinione" 52 . W doktrynie i orzecznictwie sądowym przytacza się wiele przykładów (stanów faktycznych) niezawinionego przez zainteresowanego niedopełnienia czynności procesowych w terminie, np.

Jeżeli adwokat uczynił zadość wymaganiom staranności, troskliwości i ostrożności w prowadzeniu procesu [...], jeżeli w niczym nie uchybił swoim obowiązkom, nie dopuścił się żadnego niedbalstwa, a pracownik jego biura naruszył swoje obowiązki, które w danych warunkach adwokat mógł nań włożyć lub dopuścił się jakiegokolwiek innego czynu, co spowodowało niedopełnienie

${ }^{47}$ Wyrok Wojewódzkiego Sądu Administracyjnego w Poznaniu z dnia 4 lipca 2013 r., sygn. akt. III SA/Po 1159/12.

${ }^{48}$ M. Jędrzejewska, [w:] T. Ereciński, J. Gudowski, M. Jędrzejewska, Komentarz do Kodeksu Postępowania Cywilnego. Część pierwsza. Postępowanie rozpoznawcze, t. I, Warszawa 1999, s. 322.

49 J. Krajewski, [w:] J. Jodłowski, K. Piasecki (red.), Kodeks postępowania cywilnego z komentarzem, Wydawnictwo Prawnicze, Warszawa 1989, s. 274.

${ }^{50}$ E. Iserzon, op. cit., s. 136.

${ }^{51}$ Ibidem.

${ }^{52}$ Ibidem. 
przez adwokata w terminie czynności procesowej, a adwokat przy największej ostrożności nie mógł zapobiec temu naruszeniu obowiązków lub innemu czynowi, to nie ma podstaw do przypisywania winy temu adwokatowi ${ }^{53}$.

Wniosek o przywrócenie terminu powinien odpowiadać wymaganiom stawianym pismom procesowym (art. $63 \S 2$ ). Według E. Iserzona wniosek ten „musi zawierać uzasadnienie, a mianowicie przytoczenie okoliczności świadczących o tym, że uchybienie nastąpiło bez winy [zainteresowanego - A. W.]" ${ }^{54}$. Brak uzasadnienia nie czyni jednak wniosku niedopuszczalnym, bowiem przepisy kodeksu nie ustanawiają takiego warunku. Wystarczy zatem, jeżeli wniosek zawiera żądanie przywrócenia terminu. W wyroku Naczelnego Sądu Administracyjnego w Warszawie z dnia 23 listopada 1984 r., przyjęto, że „Jeżeli strona nie wycofa skutecznie odwołania, nie jest dopuszczalne pozostawienie bez rozpoznania przez organ odwoławczy jej wniosku w sprawie przywrócenia terminu do wniesienia odwołania" ${ }^{5}$. Żądanie przywrócenia terminu musi być wyraźne. „Przepisom k.p.a. nie jest znany przypadek milczącego czy też dorozumianego przywrócenia terminu. Przywrócenie terminu uregulowane w art. 58 i n. k.p.a. może nastąpić wyłącznie na wniosek zainteresowanego" (wyrok Naczelnego Sądu Administracyjnego z dnia 10 stycznia $2008 \mathrm{r}^{56}$ ). „Sam fakt dokonania określonej czynności po terminie nie może być podstawą do domniemania, że osoba zainteresowana składa wniosek o przywrócenie terminu" (wyrok Naczelnego Sądu Administracyjnego z dnia 3 marca 2008 r.). Podobnie Naczelny Sąd Administracyjny w wyroku z dnia 1 czerwca 2010 r. ${ }^{57}$, stwierdził, iż

1. Warunkiem koniecznym rozpoznania przez organ zagadnienia przywrócenia terminu jest złożenie stosownej prośby (wniosku) przez zainteresowanego. Nie ma tu prawnej możliwości przywrócenia terminu przez organ z urzędu - bez wniosku strony. 2. Sam fakt dokonania czynności procesowej po terminie nie stwarza domniemania, że strona złożyła wniosek o przywrócenie terminu, a pogląd jakoby można było złożyć wniosek o przywrócenie terminu w sposób dorozumiany nie znajduje oparcia w przepisach administracyjnej procedury.

${ }^{53}$ Wyrok Sądu Najwyższego z dnia 11 lipca 1935 r., sygn. akt. IIIC 1146/34,OSP 1935, poz. 597.

${ }^{54}$ E. Iserzona, op. cit., s. 134.

${ }^{55}$ Wyrok Naczelnego Sądu Administracyjnego w Warszawie z dnia 23 listopada 1984 r., sygn. akt. II SA 1284/84, ONSA 1984, nr 2, poz. 111.

${ }^{56}$ Wyrok Naczelnego Sądu Administracyjnego z dnia 10 stycznia 2008 r., sygn. akt. II OSK 1822/06, LEX nr 453995) oraz wyrok Wojewódzkiego Sądu Administracyjnego w Krakowie z dnia 5 grudnia 2011, sygn. akt. II SA/Kr1453/11, LEX nr 1152826 stwierdził, iż zawarte w dziale i rozdziale 10 KPA uregulowania dotyczą obliczania terminu i wstrzymania wykonania decyzji lub postanowienia w sytuacji złożenia prośby o przywrócenie terminu do wniesienia odwołania lub zażalenia. Przepisy te adresowane są wyłącznie do stron postępowania administracyjnego.

57 Wyrok Naczelnego Sądu Administracyjnego z dnia 1 czerwca 2010 r., sygn. akt. II GSK 596/09, LEX nr 603140. 
Wyroku Naczelnego Sądu Administracyjnego z dnia 17 lutego 2012 r., w którym stwierdzono, że „Instytucja przywrócenia terminu oparta jest na zasadzie skargowości, co oznacza, że wnoszący podanie musi w sposób niebudzący wątpliwości domagać się przywrócenia uchybionego terminu" 58 .

Nawiązując do powyższego, terminy procesowe można klasyfikować na podstawie różnych kryteriów. Istotnym jest dla skutków procesowych podział na terminy ustawowe i terminy wyznaczone (sądowe). Terminy ustawowe są wyznaczone wprost w przepisach ustaw lub aktów wykonawczych wydanych na podstawie delegacji ustawowej. Terminem ustawowym będą terminy wyznaczone przez ustawę prawo o postępowaniu przed sądami administracyjnymi, np. termin do wniesienia skargi (art. 53), termin do usunięcia braków formalnych pisma procesowego (art. 49 § 1), termin do złożenia wniosku o uzupełnienie wyroku (art. 157 $\S 1$ ), termin wniesienia skargi kasacyjnej (art. 177 § 1), termin do złożenia skargi o wznowienie postępowania (art. 277). Terminy ustawowe wyznaczone stronom, podmiotom na prawach stron i uczestnikom postępowania nie mogą być przez sąd ani skracane, ani przedłużane. Zachowanie terminu ustawowego jest warunkiem skuteczności czynności procesowej dokonanej przez te podmioty. Uchybienie terminu ustawowego powoduje zatem bezskuteczność czynności procesowej. Od negatywnych skutków uchybienia terminu strona może bronić się, wyłącznie składając wniosek o przywrócenie terminu. Terminem ustawowym jest termin do przekazania skargi przez organ ${ }^{59}$. Naruszenie terminu ustawowego jest podstawą do orzeczenia przez sąd na wniosek skarżącego o wymierzeniu grzywny w wysokości dziesięciokrotnego przeciętnego wynagrodzenia miesięcznego w gospodarce narodowej w roku poprzednim, ogłoszonego przez Prezesa Głównego Urzędu Statystycznego na podstawie odrębnych przepisów ( 1 w związku z art. $154 \S 6$ ustawy prawo o postępowaniu przed sądami administracyjnymi). Terminy ustawowe mogą być zawarte w przepisach prawa i wyznaczone również dla sądu. Takim rodzajem terminu są terminy uregulowane w art. 21 pkt 2 ustawy z dnia 6 września 2001 r. o dostępie do informacji publicznej ${ }^{60}$, który stanowi „skargę rozpatruje się w terminie 30 dni od dnia otrzymania akt wraz z odpowiedzią na skargę". Do takiego rodzaju terminu należy zaliczyć terminy wyznaczone w ustawach samorządowych. Według treści art. 92a ustawy o samorządzie gminnym „W przypadku złożenia przez organ gminy skargi na rozstrzygnięcie nadzorcze, sąd administracyjny wyznacza rozprawę nie później niż w ciągu 30 dni

58 Wyrok Naczelnego Sądu Administracyjnego z dnia 17 lutego 2012 r., sygn. akt. II OSK 2287/10, LEX nr 1217.

${ }^{59}$ Według art. 54 § 2 ustawy Prawo o postępowaniu przed sądami administracyjnymi: „Organ [...] przekazuje skargę sądowi wraz z aktami sprawy i odpowiedzią na skargę w terminie trzydziestu dni od dnia jej wniesienia". Uchybienie terminu przez organ nie może być rozpatrywane na płaszczyźnie bezskuteczności czynności procesowej przekazania.

${ }^{60}$ Ustawa z dnia 6 września 2001 r. o dostępie do informacji publicznej Dz. U. nr 112, poz. 1198 z późn. zm. 
od dnia wpłynięcia skargi do sądu". Rozwiązanie to przyjmuje art. 80a ustawy z dnia 5 czerwca 1998 r. o samorządzie powiatowym ${ }^{61}$, a w art. $82 \mathrm{~b}$ ustawy z dnia 5 czerwca 1998 r. o samorządzie województwa ${ }^{62}$. Terminy ustanowione w ustawach samorządowych łączą w sobie elementy terminu ustawowego, w ciągu 30 dni i terminu sądowego, sąd wyznacza termin nie później niż w ciągu 30 dni od dnia wpłynięcia skargi. Uchybienie terminu ustawowego przez sąd administracyjny nie powoduje bezskuteczności orzekania. Brak jest bezpośrednich gwarancji prawnych przestrzegania terminów ustawowych przez sąd. Gwarancji tych szukać należy w obowiązku przestrzegania prawa przez sąd, co jest szczególnie istotne z uwagi na to, że sąd administracyjny jest powołany do rozstrzygania sporu o zgodność działania z prawem administracji publicznej. Wszelka zatem działalność wbrew przepisom prawa sądu będzie wywoływać podważenie zaufania do znaczenia sądu administracyjnego jako istotnego elementu systemu gwarancji praworządności działania organów państwa ${ }^{63}$.

Terminy sądowe są wyznaczane przez sąd lub przewodniczącego. Przewodniczący może z ważnej przyczyny przedłużyć termin sądowy z urzędu lub wniosku strony zgłoszony przed upływem terminu, a także skrócić termin sądowy na wniosek strony. Według ustawy Prawo o postępowaniu przed sądami administracyjnymi terminy sądowe to: terminy wyznaczone przez sąd do usunięcia braków w zakresie zdolności sądowej lub procesowej albo w składzie właściwych organów (art. $31 \S 1$ ), wyznaczenie terminu przedstawienia pełnomocnictwa (art. 44 $\S 2$ ), wyznaczenie terminu rozprawy (art. $91 \S 1$ ). Uchybienie terminu sądowego w zależności od tego, jakiej czynności dotyczy, wywołuje różne następstwa prawne. Uchybienie terminu do dokonania czynności przez stronę powoduje jej bezskuteczność, np. nieuzupełnienie braków w zakresie zdolności sądowej lub procesowej powoduje, że sąd zniesie postępowanie w zakresie, w jakim było ono do pełnomocnictwa, sąd pominie czynności procesowe podjęte przez tę osobę. Niezachowanie terminu stawienia się na rozprawę ma tylko znaczenie dla możliwości obrony interesu prawnego przez skarżącego, a po stronie organu wykonującego administrację publiczną - obrony zgodności z prawem podjętego działania lub bezczynności ${ }^{64}$. Datą, od której należy liczyć termin do wniesienia wniosku o przywrócenie terminu, jest także data uzyskania przez zainteresowaną osobę wiadomości o zdarzeniu powodującym rozpoczęcie biegu terminu. Jeśli strona nie wiedziała o uchybieniu terminu, to termin do złożenia prośby o jego przywrócenie liczy się od daty uzyskania wiadomości o tym, że odwołanie zostało złożone z uchybieniem terminu (wyrok Wojewódzkiego Sądu Administracyjnego w Rze-

${ }^{61}$ Ustawa z dnia 5 czerwca 1998 r. o samorządzie powiatowym, t.j. Dz. U. nr 91, poz. 578 z późn. zm.

${ }^{62}$ Ustawa z dnia 5 czerwca 1998 r. o samorządzie województwa, t.j. Dz. U. nr 91, poz. 576 z późn. $\mathrm{zm}$.

${ }_{63}^{63}$ B. Adamiak, J. Borkowski, op. cit., s. 407-408.

${ }^{64}$ Ibidem. 
szowie z dnia 11 grudnia $2013 \mathrm{r}^{65}$ ). Na przykład Powiatowy Inspektorat Nadzoru Budowlanego nakazał inwestorowi rozbiórkę budynku. W decyzji zawarto prawidłowe pouczenie o terminie i trybie złożenia odwołania. Decyzja ta została przesłana za zwrotnym potwierdzeniem odbioru na adres inwestora ${ }^{66}$. Przesyłkę z dnia 30 kwietnia 2014 r. odebrała żona adresata. Zapomniała ona poinformować męża o odebranej przesyłce. Dokonała tego dopiero w dniu 16 maja 2014 r., natomiast inwestor wniósł odwołanie od decyzji wraz z wnioskiem o przywrócenie terminu, który upłynął w dniu 15 maja 2014 r. Siedmiodniowy termin na wniesienie tego wniosku zaczął biec od następnego dnia, od kiedy inwestor dowiedział się o przesyłce, czyli w dniu17 maja 2014 r. Warunkiem przywrócenia terminu jest wniesienie wniosku oraz jednoczesne dopełnienie czynności, dla której był on określony. Przykładowo, gdy przedsiębiorca wnosi o przywrócenie terminu do wniesienia odwołania musi on go dołączyć do wniosku. Możliwe jest ich sformułowanie $\mathrm{w}$ jednym piśmie skierowanym do organu (wyrok Wojewódzkiego Sądu Administracyjnego w Gliwicach z dnia 16 czerwca $2011 \mathrm{r}^{67}$ ). W tej kwestii przepisy Kodeksu postępowania administracyjnego zajęły klarowne stanowisko i precyzyjnie określiły, w jaki sposób należy prawidłowo obliczyć termin. Jest to niezmiernie istotne, bowiem błąd $\mathrm{w}$ ich obliczaniu będzie miał negatywne skutki. Na pewno nie będziemy mogli wykonać czynności procesowej, a o przywróceniu terminu raczej nie powinniśmy $\mathrm{w}$ tym przypadku myśleć. Nie jest to przesłanka uzasadniająca brak winy. W myśl art. 57 KPA określa, w jaki sposób należy obliczyć terminy. Jeżeli początkiem terminu określonego w dniach jest pewne zdarzenie, przy obliczaniu tego terminu nie uwzględnia się dnia, w którym zdarzenie to nastąpiło. Co to oznacza w praktyce? Otóż dzień np. wydawania decyzji nie jest uwzględniany przy obliczaniu terminu. Dopiero dzień następny jest brany pod uwagę. Upływ ostatniego z wyznaczonej liczby dni uważa się za koniec terminu. Zgodnie $z$ art. 57 § 4 KPA oraz 82 p.p.s.a., jeżeli koniec terminu przypada na dzień ustawowo wolny od pracy, za ostatni dzień terminu uważa się najbliższy następny dzień powszedni ${ }^{68}$. Sobota jest dniem ustawowo wolnym od pracy. W kwestii tej

${ }^{65}$ Wyrok Wojewódzkiego Sądu Administracyjnego w Rzeszowie z dnia 11 grudnia 2013 r., sygn. akt. II SA/Rz 1032/13.

${ }^{66}$ Nieumieszczenie na drzwiach mieszkania adresata albo biura lub innego pomieszczenia, w którym adresat wykonuje swoje czynności zawodowe (bądź w miejscu widocznym na nieruchomości, której postępowanie dotyczy), zawiadomienia o złożeniu pisma w placówce pocztowej (urzędzie gminy) oznacza, iż wezwanie skierowane do strony postępowania przed Naczelnym Sądem Administracyjnym nie zostało prawidłowo doręczone (art. 44 KPA w związku z art. 59 ustawy z dnia 11 maja 1995 r. o Naczelnym Sądzie Administracyjnym (Dz. U. nr 74, poz. 368 z późn. zm.) - Postanowienie Sądu Najwyższego z dnia 9 czerwca 1999 r., sygn. akt. III RN 17/99, OSNIAPiUS 2000, nr 10, poz. 379.

${ }^{67}$ Wyrok Wojewódzkiego Sądu Administracyjnego w Gliwicach z dnia 16 czerwca 2011 r., sygn. akt. II SA/GI 1334/10.

${ }^{68}$ Wyrok Wojewódzkiego Sądu Administracyjnego w Krakowie z dnia 3 kwietnia 2014 r., sygn. akt. III SA/Kr 1502 Lex nr 1526197 stwierdził, iż przepisy KPA wiążą skutek procesowy 
wypowiedział się w uchwale z dnia 17 grudnia 1987 r. Sąd Najwyższy, stwierdzając, iż

dodatkowe dni wolne od pracy wprowadzone na zasadach i trybie przewidzianym w przepisach wykonawczych, wydawanych na podstawie art. 150 K.p. nie są w rozumieniu art. 165 § 1 K.p.c. w zw. $\mathrm{z}$ art. 115 K.c. ustawowo uznanymi za wolne od pracy ${ }^{69}$.

Na gruncie procedury karnej Sąd Najwyższy w uchwale z dnia 20 września 1996 r. wyraził pogląd, iż

dodatkowe dni wolne od pracy, wyznaczone zarządzaniem Ministra Pracy i Polityki Socjalnej z dnia 8 grudnia 1995 r. w sprawie określenia terminów dodatkowych dni wolnych od pracy w $1996 \mathrm{r}$. (M.P. nr 69, poz. 702) są dniami uznanymi przez ustawę za dni wolne od pracy w rozumieniu art. $108 \S 3$ k.p.k. ${ }^{70}$.

Na gruncie procedury cywilnej taki sam pogląd przyjęto dopiero w postępowaniu z dnia 3 grudnia 1997 r., sygn. akt. III RN 87/97, podjętej wskutek wniesienia wspomnianej rewizji nadzwyczajnej Prokuratora Generalnego. W postępowaniu tym stwierdzono, że

jeżeli koniec terminu do dokonania czynności procesowej przypada na dzień uznany ustawowo za wolny od pracy, w tym powszechnie obowiązujący dodatkowy dzień wolny od pracy, wprowadzony w okresie obowiązywania art. 150 k.p. ${ }^{71}$ oraz wydanych na jego podstawie $\S 1$ ust. 3 rozporządzenia Rady Ministrów z dnia 23 grudnia 1988 r. w sprawie czasu pracy w zakładach pracy (t.j. Dz. U. z 1991 r. nr 117, poz. 511 z późn. zm.), to za ostatni dzień terminu należy uważać najbliższy dzień powszechny ${ }^{72}$.

z dniami ustawowo wolnymi od pracy tylko w sytuacji, gdy ostatni dzień terminu przypada w tych dniach i wtedy termin do złożenia pisma procesowego upływa najbliższego dnia roboczego. W przypadku, gdy dni ustawowo wolne od pracy są objęte terminem, nie ma podstaw prawnych, aby tych dni nie uwzględniać przy obliczaniu terminu. Podkreślić należy również, że błędne odczytanie skierowanego do skarżącego pouczenia, ani też niewiedza skarżącego co do zasad obliczania terminu nie mogą być uznane za okoliczności usprawiedliwiające uchybienie terminu do wniesienia odwołania.

${ }^{69}$ Uchwała Sądu Najwyższego z dnia 17 grudnia 1987 r., sygn. akt. III CZP 81/87 oraz Podobny pogląd na gruncie procedury karnej reprezentowała uchwała $\mathrm{z}$ dnia 29 grudnia 1987 r., sygn. akt. VI KZP 35/87, OSNKW 1988, nr3-4, poz. 20.

${ }^{70}$ Uchwała Sądu Najwyższego z dnia 20 września 1996 r., sygn. akt. I KZP20/96, OSNKW 1996, nr 11-12, poz. 80.

${ }^{71}$ Ustawa z dnia 26 czerwca 1974 r. Kodeks pracy (k.p.), Dz. U. 1974, nr 24, poz. 141 z późn. zm.

72 Postanowienie Sądu Najwyższego z dnia 3 grudnia 1997 r., sygn. akt. III RN 87/97, natomiast we wcześniejszym postanowieniu z dnia 9 kwietnia 1997 r., sygn. akt. I PKN 81/97, OSNIAPiUS 19998, nr 3 poz. 86 Sąd Najwyższy stwierdził, że dodatkowe dni wolne od pracy określone w art. 150 k.p. w brzmieniu sprzed nowelizacji dokonanej ustawą z dnia 2 lutego 1996 r., sygn. akt. OSNIAPiUS 1998, nr 14, poz. 414 o zmianie ustawy Kodeks pracy oraz zmianie niektórych ustaw (Dz. U. nr 24, poz. 110 z późn. zm.) oraz art. 1291 § 1 k.p. nie są dniami ustawowo wolnymi od pracy w rozumieniu art. $156 \S 1$ k.p.c. w zw. z art. 115 k.c. 
W wyroku z dnia 4 czerwca 1993 r. Naczelny Sąd Administracyjny stwierdził, że wobec jednakowej w istocie art. 57 § 4 KPA i art. 115 k.c. brak jest podstaw do różnicowania pojęcia „dzień ustawowo wolny od pracy” w postępowaniu cywilnym oraz administracyjnym. Obecnie na mocy art. 157 (7) k.p. sposób wprowadzenia i terminy dodatkowych dni wolnych od pracy określa się w układzie zbiorowym pracy lub regulaminie pracy ${ }^{73}$. W uchwale z dnia 15 czerwca 2011 r. Naczelny Sąd Administracyjny Warszawie stwierdził, iż sobota to dzień ustawowo wolny od pracy w rozumieniu art. 57 § 4 KPA. Wskazał, iż ustawodawca w innych procedurach wyraźnie określił, iż w przypadku gdy ostatni dzień terminu przypada na sobotę, za ostatni dzień terminu uważa się następny po dniu wolnym od pracy (np. art. $83 \S 2$ p.p.s.a) i oznacza to tylko, iż w tych procedurach usunięte zostało źródło wątpliwości interpretacyjnych. Nie może być to argument przemawiający za stanowiskiem, że wolą ustawodawcy było przyjęcie takiego unormowania, aby w ogólnym postępowaniu administracyjnym sobota nie była traktowana jako dzień ustawowo wolny od pracy $^{74}$. Przepisy dotyczące obliczania i przywracania terminów na gruncie postępowania podatkowego uwzględniają istniejący w prawie podatkowym podział terminów. Wynika to z często stosowanej w prawie podatkowym konstrukcji ograniczenia praw lub obowiązków terminami przedawnienia oraz innymi terminami materialnymi do dokonania określonych czynności. Z tego względu w art. 12 ustawy ordynacji podatkowej zawartym w Dziale I obejmującym przepisy ogólne unormowano sposób obliczenia terminów określonych $\mathrm{w}$ dniach, tygodniach, miesiącach i latach na potrzeby zobowiązań podatkowych i postępowania podatkowego. W rozdziale 7 Działu IV, w art. 162-164 ustawy ordynacji podatkowej uregulowano jedynie kwestię przywrócenia terminu. Zasadniczo zastosowane rozwiązania prawne są bardzo bliskie konstrukcjom KPA. Odmiennie niż w kodeksie rozwiązano w ordynacji sposób liczenia terminu w odniesieniu do wolnych sobót. Zgodnie z art. $12 \S 5$ ustawy ordynacji podatkowej, jeżeli ostatni dzień terminu przypada na sobotę lub dzień ustawowo wolny od pracy, to za ostatni dzień terminu uważa się następny dzień po dniu lub dniach wolnych od pracy. Artykuł 57 § 4 KPA mówi jedynie o sytuacji, gdy koniec terminu przypadał na dzień ustawowo wolny od pracy, co rodziło trudności w wykładni tego przepisu ${ }^{75}$. Na uwagę zasługuje tu regulacja art. 162 $\S 4$ ustawy ordynacji podatkowej, która nie ma swojego odpowiednika w KPA W tekście ustawy ordynacji podatkowej zawarto wyraźnie stwierdzenie, iż przepisy dotyczące przywrócenia terminów mają zastosowanie tylko do terminów procesowych. Jedynie terminy przewidziane dla czynności proceduralnych podlegają

${ }^{73}$ Wyrok Naczelnego Sądu Administracyjnego z dnia 4 czerwca 1993 r., sygn. akt SA/Wr $429 / 93$.

${ }^{74}$ Uchwała Naczelnego Sądu Administracyjnego Warszawie z dnia 15 czerwca 2011 r., sygn. akt IOPS 1/11, ONSAiAWSA.

${ }^{75}$ Por. stanowisko wyrażone w tej sprawie przez Sąd Najwyższy w postępowaniu z dnia 3 lutego 2000 r., sygn. akt. III RN 195/99, OSP 2001, nr 5, poz. 78, z glosą T. Kuczyńskiego. 
przywróceniu, co odróżnia je od terminów materialnoprawnych. Zasadniczo nie ma co do tego wątpliwości, ponieważ jednak w orzecznictwie Naczelnego Sądu Administracyjnego pojawiły się skargi w sprawach, których przedmiotem były postanowienia $\mathrm{w}$ sprawie przywrócenia terminów materialnoprawnych, stwierdzenie niedopuszczalności przywracania takich terminów wydaje się zasadne ${ }^{76}$. Terminy wynikające z treści art. $57 \S 1 \mathrm{KPA}$ oraz art. 82 p.p.s.a. oblicza się według przepisów prawa cywilnego z zastrzeżeniem rozwiązania przyjętego $\mathrm{w}$ art. $83 \S 2$ ustawy prawo o postępowaniu przed sądami administracyjnymi, który stanowi „Jeżeli ostatni dzień terminu przypada na sobotę lub dzień ustawowo wolny od pracy, za ostatni dzień terminu uważa się następny dzień po dniu lub dniach wolnych od pracy". Upływ ostatniego z wyznaczonej liczby dni uważa się za koniec terminu. Pamiętać tu należy, iż bez znaczenia dla sprawy jest data odnotowania otrzymanej korespondencji przez skarżącą w dzienniku podawczym ${ }^{77}$. Rzeczą podmiotu prowadzącego działalność gospodarczą, korzystającego z obsługi prawnej, jest przeszkolenie podległych pracowników tak co do prawidłowego odbioru korespondencji, jak i jej obiegu celem zachowania terminów do złożenia odwołania. Wszelkie błędy popełnione przez podległych pracowników obciążają osobę skarżącą jako pracodawcę ${ }^{78}$. Zgodnie z art. $53 \S 1$ ustawy prawo o postępowaniu przed sądami administracyjnymi skargę wnosi się w terminie 30 dni od dnia doręczenia skarżącemu rozstrzygnięcia w sprawie. W przypadkach, o których mowa w treści art. 52 § 3 i 4 tej ustawy, czyli dot. skargi na inne niż decyzje lub czynności, skargę wnosi się w terminie 30 dni od dnia doręczenia odpowiedzi organu na wezwanie do usunięcia naruszenia prawa, a jeżeli organ nie udzieli odpowiedzi na wezwanie - w terminie 60 dni od dnia wniesienia wezwania do usunięcia naruszenia prawa (art. 53 § 2 p.p.s.a.). W myśl art. 82 p.p.s.a. bieg terminu wyznaczonego przez sąd lub przewodniczącego (termin sądowy) rozpoczyna się od ogłoszenia w tym przedmiocie postanowienia lub zarządzenia, a gdy ustawa przewiduje doręczenie z urzędu - od jego doręczenia.

76 Wyrok Naczelnego Sądu Administracyjnego z dnia 24 listopada 1994 r. Sąd stwierdził, iż w sprawie skargi na odnowę przywrócenia terminu do wyboru zwolnienia na podstawie art. 48 ustawy z dnia 8 stycznia 1993 r. o podatku od towarów i usług oraz podatku akcyzowym (Dz. U. nr 11, poz. 50 z późn. zm.) na podstawie art. 58 i 59 KPA stwierdził, iż „Należy przyjąć, iż podobnie jak na gruncie prawa cywilnego również $\mathrm{w}$ prawie administracyjnym przepisami procesowymi będą przepisy o właściwości administracyjnego organu orzekającego i o postępowaniu przed takim organem w sprawach przewidzianych Kodeksem postępowania administracyjnego. Przepisy dotyczące przesłanek, treści, powstania, zmiany lub zgaśnięcia prawa czy roszczenia materialnego należą do przepisów materialnoprawnych".

77 Wyrok Wojewódzkiego Sądu Administracyjnego z dnia 9 września 2010 r., sygn. akt. IISA/ GI 252/10. Sąd stwierdził, iż brak nadania przesyłki skutkuje brakiem dowodu na okoliczność daty nadania przesyłki w urzędzie pocztowym, a także dowodzi, że przesyłka ta była nadesłana za pośrednictwem poczty.

${ }^{78}$ Wyrok Naczelnego Sądu Administracyjnego z dnia 13 marca 2000 r., sygn. akt. V SA 821/99, OSP 2000, z. 10, poz. 159. 
Właściwość organu administracji publicznej do rozpatrzenia sprawy o przywrócenie terminu określają 59 § 1 i 2 KPA. Artykuł ten w odniesieniu do pozostałych terminów procesowych ustanawia zasadę, zgodnie z którą o przywróceniu terminu postanawia właściwy w sprawie organ administracji publicznej. Przez organ „właściwy w sprawie” należy rozumieć „organ administracji publicznej, który jest właściwy do załatwienia sprawy administracyjnej w formie decyzji" ${ }^{\prime \prime}$. W świetle art. $127 \S 2$ KPA organ administracji publicznej wyższego stopnia, chyba że ustawa przewiduje inny organ odwoławczy. O przywróceniu terminu do wniesienia zażalenia postanawia organ właściwy do rozpatrzenia zażalenia, tzn. na podstawie art. $144 \mathrm{w}$ zw. z art. $127 \S 2$ KPA organ administracji publicznej wyższego stopnia, chyba że ustawa przewiduje inny organ odwoławczy. Pamiętać tu należy, iż podanie zawierające żądanie przywrócenia terminu dokonania czynności procesowej należy wnieść do właściwego organu w terminie siedmiu dni od dnia ustania przyczyny uchybienia terminowi. „Jeżeli wniosek o przywrócenie terminu do wniesienia odwołania od decyzji organu administracji państwowej I instancji został mylnie skierowany do Naczelnego Sądu Administracyjnego, to Sąd ten na podstawie art. $200 \S 2$ k.p.c. w zw. z art. 211 KPA winien przekazać go do rozpoznania właściwemu organowi administracyjnemu" (postanowienie Naczelnego Sądu Administracyjnego w Warszawie z dnia 10 grudnia $1991 \mathrm{r}^{80}$ ). Ustanie przyczyny uchybienia terminu to $\mathrm{z}$ reguły ustanie przeszkody niemożliwej do przezwyciężenia przez zainteresowanego, który dołożył należytej staranności. Ocena, czy strona dochowała terminu wniesienia wniosku o przywrócenie terminu, a w szczególności, czy przeszkoda ustała w dniu, w którym w mniemaniu zainteresowanego ustała przyczyna uchybienia, należy do organu administracji publicznej, który może odmówić przywrócenia terminu z powodu spóźnienia wniosku. Termin złożenia wniosku o przywrócenie terminu nie może być przywrócony (art. $58 \S 3 \mathrm{KPA}$ ). Zgodnie z art. $59 \S 1 \mathrm{KPA}$ zdanie pierwsze o przywróceniu terminu postanawia właściwy w sprawie organ administracji publicznej. Z literalnego brzmienia tego przepisu wynika, iż organem właściwym w sprawie przywrócenia terminu jest organ administracji publicznej, który jest właściwy do załatwienia sprawy administracyjnej w formie decyzji. W związku z tym należy przyjąć, iż nawet wówczas, gdy zainteresowany uchybił terminowi dokonania czynności procesowej przed organem, o którym mowa w art. 52 KPA, wniosek o przywrócenie terminu powinien złożyć do organu właściwego w sprawie. Odmiennie w tej kwestii twierdzi E. Iserzon, który jest zdania, że „Właściwym w sprawie przywrócenia terminu organem administracji państwowej jest

${ }^{79}$ A. Wróblewski, [w:] M. Jaśkowska, Kodeks postępowania administracyjnego, komentarz, Lexis Nexis, Warszawa 2013, s. 373-374.

${ }^{80}$ Postanowienie Naczelnego Sądu Administracyjnego w Warszawie z dnia 10 grudnia $1991 \mathrm{r}$., sygn. akt. III SA 997/91, OSP 1995, z. 4, poz. 86, z glosą B. Adamiak; OSP 1995, z. 4, poz. 86, s. 179 , z glosą S. Dalki. 
z reguły organ, wobec którego czynność miała być dokonana"81. Od tej zasady art. $59 \S 2$ KPA przewiduje wyjątek, bowiem zgodnie z tym artykułem o przywrócenie terminu wniesienia odwołania lub zażalenia postanowienia ostatecznie organ właściwy w sprawie, chyba że ustawa przewiduje inny organ odwoławczy (art. 127 § 2 KPA). W kwestii tej w wyroku z dnia 24 września 2008 r. Naczelny Sąd Administracyjny stwierdził, iż

Gdy strona wraz z wniesieniem odwołania składa wniosek o przywrócenie terminu wniesienia odwołania (art. 59 § 2 k.p.a.), wyłączona zostaje możliwość wydania odrębnego postanowienia na podstawie art. 134 k.p.a., stwierdzającego uchybienie terminu wniesienia odwołania ${ }^{82}$.

Na postanowienie wydane w wyniku zażalenia na postanowienie o odmowie przywrócenia terminu, wydane na podstawie art. 59 § $1 \mathrm{KPA}$, służy skarga do wojewódzkiego sądu administracyjnego. Na postanowienie wydane na podstawie art. $59 \S 2$ KPA nie służy zażalenie, jednakże postanowienie to podlega zaskarżeniu do wojewódzkiego sądu administracyjnego (art. $3 \S 2$ pkt. 2 p.p.s.a.) ${ }^{83}$. $Z$ pierwszego ograniczenia wynika, iż w przypadku uzyskania zgody (nawet $\mathrm{z}$ naruszeniem prawa) na przywrócenie terminu dla jednego z przedmiotów, interesy pozostałych podmiotów postępowania, o ile takie istnieją, nie są w żaden sposób chronione. W przypadku gdy wniosek o przywrócenie terminu dotyczy terminu do wniesienia odwołania od decyzji lub zażalenia od postanowienia, strona zyskuje uprawnienie żądania do organu, aby ten wstrzymał ich wykonanie.

Sąd administracyjny rozpatruje wniosek o przywrócenie terminu na posiedzeniu niejawnym. Ocena spełnienia przesłanek należy do sądu. Po rozpoznaniu wniosku sąd $\mathrm{w}$ formie postanowienia orzeka o przywróceniu lub odmowie przywrócenia terminu (art. $86 \S 3$ p.p.s.a.). Spóźniony lub z mocy ustawy niedopuszczalny wniosek o przywrócenie terminu sąd odrzuci na posiedzeniu niejawnym.

${ }^{81}$ E. Iserzon, J. Starościak, op. cit., s. 140.

${ }^{82}$ Wyrok Naczelnego Sądu Administracyjnego z dnia 24 września 2008 r., sygn. akt. I OSK 1490/07, ONSA WSA 2009, nr 3, poz. 55.

83 Wyrok Sądu Najwyższego z dnia 29 marca 1988 r., sygn. akt. III ARN 7/88, OSNC 1990, nr 9, poz. 117, w którym przyjęto, iż „O przywróceniu terminu do wniesienia odwołania lub zażalenia organ właściwy do ich rozpatrzenia postanawia ostatecznie (art. $59 \S 2 \mathrm{kpa}$ ). Podobnie jak ostateczne jest postanowienie organu odwoławczego o niedopuszczalności odwołania (zażalenia) lub uchybieniu terminu do ich wniesienia (art. 134 zdanie drugie i art. $144 \mathrm{kpa}$ )"; por. także wyrok Naczelnego Sądu Administracyjnego z dnia 21 stycznia 2010 r., sygn. akt. II OSK 120/09, LEX nr 597160, zgodnie z którym: „Postanowienia wydawane przez organ odwoławczy na podstawie art. $59 \S 2 \mathrm{kpa}$, jak postanowienia wydane na podstawie art. $134 \mathrm{kpa}$ są ostateczne i służy na nie wyłącznie skarga do sądu administracyjnego" oraz wyrok Naczelnego Sądu Administracyjnego w Szczecinie z dnia 23 października 1998 r., sygn. akt. SA/Sz 1115/97, Biul. Skarb. 1999, nr 1, s. 32, przyjęto, iż „Naczelny Sąd Administracyjny nie może przywrócić stronie terminu do wniesienia odwołania od decyzji organu I instancji, albowiem kompetencja taka przysługuje organowi odwoławczemu (art. $59 \S 2 \mathrm{kpa}$ ), którego ewentualne postanowienie o odmowie przywrócenia terminu podlega zaskarżeniu do Naczelnego Sądu Administracyjnego". 
Na postanowienie o odrzuceniu wniosku przysługuje zażalenie (art. 88 ustawy prawo o postępowaniu przed sądami administracyjnymi). Spóźniony wniosek to wniosek złożony po upływie 7-dniowego terminu od ustania przyczyny uchybienia terminu. Niedopuszczalny wniosek to wniosek o przywrócenie terminu, który nie jest terminem procesowym, a terminem materialnoprawnym. Powyższe zagadnienie obowiązuje także na gruncie ordynacji podatkowej. Rozstrzygnięcie dotyczące przywrócenia terminu ma formę postanowienia. Na postanowienie wydane w trybie art. $163 \S 2$ ustawy ordynacja podatkowa, a więc odmawiające przywrócenia terminu wniesienia odwołania, zażalenie nie przysługuje, ponieważ art. 162 $\S 2$ ordynacji podatkowej stanowi, że rozstrzyga o tym właściwy organ w sposób ostateczny. Wnosząc o przywrócenie terminu wniesienia odwołania albo zażalenia, strona może jednocześnie zwrócić się z prośbą o wstrzymanie wykonania decyzji czy postanowienia. $Z$ powyższego można wnioskować, iż podatnik ma prawo wyboru i może np. celowo odczekać i nie składać wniosku o wstrzymanie decyzji wraz z odwołaniem dopóki organ podatkowy nie prześle akt sprawy do instancji odwoławczej. Nie można wykluczyć sytuacji, że organ odwoławczy będzie bardziej skory do wstrzymania decyzji podatkowej niż organ, który sam jest jej autorem (art. 139-141, art. 162-163, art. 216, art. 224, art. 235, art. 237 ustawy ordynacja podatkowa). Podobnie art. 89 ustawy prawo o postępowaniu przed sądami administracyjnymi reguluje moc wniosku o przywrócenie terminu „Zgłoszenie wniosku o przywrócenie terminu nie wstrzymuje postępowania w sprawie ani wykonania orzeczenia. Sąd może jednak, stosownie do okoliczności, wstrzymać postępowanie lub wykonanie orzeczenia. Postanowienie może być wydane na posiedzeniu niejawnym [...]". Postępowanie, którego przedmiotem jest rozpoznanie i rozstrzygnięcie wniosku o przywrócenie terminu, jest postępowaniem incydentalnym. Dla rozpoznania wniosku nie musi być wyznaczone posiedzenie dotyczące tylko jego rozpoznania i rozstrzygnięcia. Wniosek o przywrócenie terminu może zostać rozstrzygnięty na posiedzeniu wyznaczonym w celu rozpoznania i rozstrzygnięcia sprawy. W sytuacji gdy strona wnosi jednocześnie wniosek o przywrócenie terminu i zażalenie na postanowienie o odrzuceniu środka zaskarżenia z powodu uchybienia terminowi do dokonania czynności, w pierwszej kolejności powinien zostać rozpoznany środek zaskarżenia, a dopiero po uprawnieniu się orzeczenia stwierdzającego uchybienie terminu do dokonania czynności wniosek o przywrócenie terminu. Jeśli treść wniosku nie pozwala na jednoznaczne stwierdzenie faktu uchybienia terminu do złożenia wniosku o przywrócenie terminu, postanowienie o odrzuceniu wniosku o przywrócenie terminu nie może zostać wydane na posiedzeniu niejawnym. W takim przypadku wyznacza się rozprawę.

Reasumując, upływ terminu na wniesienie odwołania od decyzji w niektórych wypadkach nie wyklucza dalszej walki o własne interesy. Szybka reakcja, należycie przedstawione argumenty i dowody są w stanie odblokować drogę dochodzenia praw przed organami administracyjnymi nawet w sytuacji, gdy na pierwszy rzut oka wydaje się, że nic już nie można zrobić. Ma to niezwykle istotne znaczenie, gdy 
decyzją organu pierwszej instancji orzeczono nakaz rozbiórki budowli, co stanowi najczęściej niezwykle dotkliwą sankcję, po którą organ administracji może sięgać tylko w wyjątkowych sytuacjach, przewidzianych wprost w ustawie.

\title{
BIBLIOGRAFIA
}

Adamiak Barbara, Borkowski Janusz. 1996. Kodeks postępowania administracyjnego. Komentarz, Warszawa: Lexis Nexis.

Adamiak Barbara, Borkowski Janusz. 1996. Postępowanie administracyjne i sądowoadministracyjne. Warszawa: Wydawnictwo Prawnicze LexisNexis.

Borkowski J., Jendrośka J., Orzechowski R., Zieliński A. 1985. Kodeks postępowania administracyjnego. Komentarz, Warszawa.

Iserzon Emanuel. 1968. Prawo administracyjne podstawowe instytucje. Warszawa: Wydawnictwo Prawnicze.

Iserzon Emanuel, Starościak Jerzy. 1970. Kodeks postępowania administracyjnego: komentarz, teksty, wzory i formularze. Warszawa: Wydawnictwo Prawnicze.

Krajewski Jan. 1989. W Kodeks postępowania cywilnego z komentarzem. Red. Jodłowski Jerzy, Kazimierz Piasecki. Warszawa: Wydawnictwo Prawnicze.

Pokrzywnicki Jerzy. 1948. Postępowanie administracyjne. Komentarz - podręcznik. Warszawa: Nakł. Gospodarczego Zrzeszenia Samorządu Terytorialnego.

Wolter Aleksander. 1967. Prawo cywilne: zarys części ogólnej. Warszawa: PWN.

Wróbel Andrzej, Jaśkowska Małgorzata. 2013. Kodeks postępowania administracyjnego: komentarz Lex. Warszawa: Lex a Wolters Kluwer business.

\section{Karolina Muzyczka}

\section{RESTORATION OF THE TERM IN THE ADMINISTRATIVE PROCEEDINGS}

\begin{abstract}
There are two basic types of terms in administrative proceedings. The first kind of terms concerns those which result directly from an act (these are in turn divided into final and instructional deadlines), the second type concerns extra periods and deadlines set by the administrative authority conducting the case. The main difference between the final and instructional terms boils down to the legal consequences that occur after non-compliance with them. In case of exceeding the limitation period by a party it comes to the ineffectiveness of the activities undertaken, while exceeding the limitation period by a body, in turn, causes a loss of its jurisdiction to rule in a matter. If you exceed the instructional term there are no such important legal consequences. Instructional deadlines can be either lengthened or shortened. This means that the party does not lose their right definitely to present specific requests. It is worth noting, however, that if you exceed the final deadline it is still possible to restore it. Restoration of term is always at the request of parties. Under binding provisions a party has seven days to present an application. This time limit begins from the moment (as of) cessation of a reason for failure.
\end{abstract}

Keywords: deadlines, principle of calculating time limits, failure to meet a deadline, application for restoration of a term, a competent authority. 